\title{
MRS Bulletin Volume Organizers Guide Technical Theme Topics for 2000
}

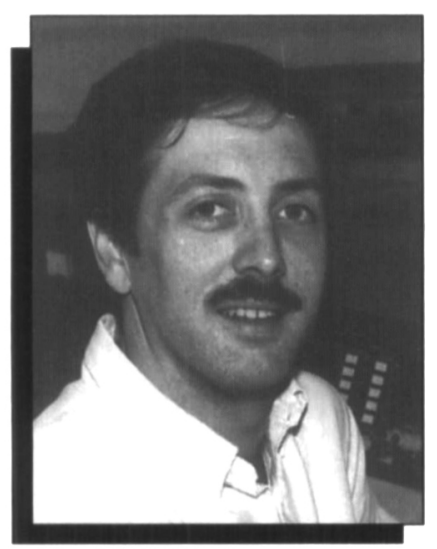

David C. Martin

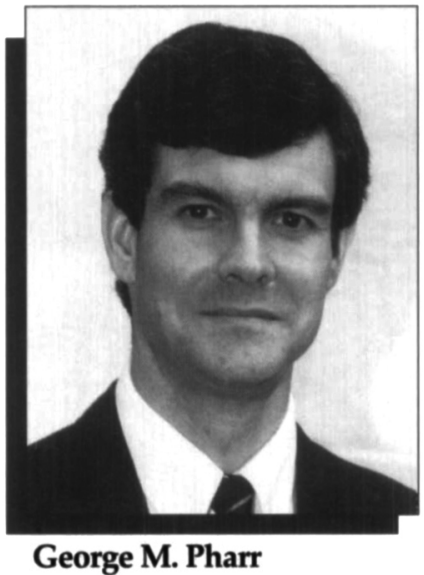

George M. Pharr

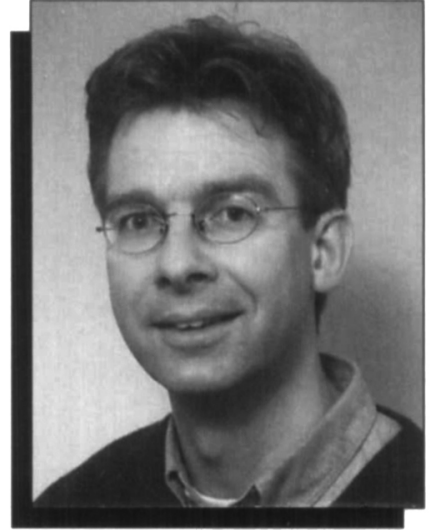

Albert Polman
The MRS Bulletin Volume Organizers for 2000 are David C. Martin (University of Michigan), George M. Pharr (University of Tennessee), and Albert Polman (FOM institute). This year, MRS Bulletin will cover a range of topical themes of current interest in materials research. With an increasing interest in the use of materials in medicine, the first issue focuses on reconstructive biomaterials. The ability to rationally design molecular and molecular complexes and assemblies will be demonstrated in the topic of supramolecular materials. New inorganic materials chemistries will be discussed in issues focused on solid electrolytes, transparent conductors, and an issue devoted to "soft processing" using precursor routes. Processing will also be addressed in an issue on thermal spray coatings, as well as the use of focused $\mathrm{MeV}$ ion beams for analysis and microfabrication. Simulations and theory are finding increased utility for materials development and evaluation, which will be discussed in the context of fracture and failure. Finally, there is still interest in well-established materials which retain high commercial impact. Hence, one issue of this volume's Bulletin will focus on defects and diffusion in silicon processing. For a list of topics and guest editors for 2000, access the $M R S$ Bulletin website at / www.mrs.org/.

David C. Martin is an associate professor in the Materials Science and Engineering Department at the University of Michigan, where he received his BS (1983) and MS (1985) degrees. He received his $\mathrm{PhD}$ degree in 1989 from the University of Massachusetts-Amherst.

In 1992, he was named a National Science Foundation National Young Investigator. From 1997 to 1998 he was a Humboldt Fellow at the Max-Planck Institute for Polymer Research in Mainz, Germany. Martin's research focuses on high resolution studies of the micromech- anisms of deformation and failure in polymer solids, molecular engineering of highstrength polymer fibers, crystal structure and its evolution in polymers, grain boundaries and dislocations in polymer solids, the structure and properties of polymers near surfaces, and the morphology of synthetic poly(peptides) produced by genetic engineering techniques. Along with serving as a volume organizer for $M R S$ Bulletin, Martin served as co-guest editor for the September 1995 issue of $M R S$ Bulletin on the topic of defects in polymers.

George M. Pharr is a professor in the Materials Science and Engineering Department at the University of Tennessee and a collaborating scientist at the Metals and Ceramics Division of the Oak Ridge National Laboratory. His research focuses on mechanical behavior of materials, nanoindentation, and thin film mechanical properties. After receiving his PhD degree in materials science and engineering from Stanford University in 1979, he pursued one year of postdoctoral studies in the Engineering Department of the University of Cambridge, England, and then joined the faculty of the Department of Mechanical Engineering and Materials Science at Rice University where he served until moving to his current position at the University of Tennessee in 1998. During a sabbatical leave in 19871988 , he worked as a visiting scientist with the Ceramic Sciences Group at the IBM Thomas J. Watson Research Center in Yorktown Heights, NY. In 1985, he received ASM International's Bradley Stoughton Award for Young Teachers of Metallurgy and was elected a Fellow of ASM International in 1995.

Pharr is an associate editor of the Journal of the American Ceramic Society. Along with serving MRS as a volume organizer for MRS Bulletin, Pharr co-authored an article in the July 1992 issue of MRS Bulletin on the mechanical behavior of thin films, coorganized a symposium on Thin Films Stresses and Mechanical Properties at the 1990 MRS Spring Meeting, and co-chaired the 1995 MRS Spring Meeting in San Francisco.

Albert Polman is a scientific group leader and head of the Optoelectronic Materials Department at the FOM-Institute for Atomic and Molecular Physics (AMOLF) in Amsterdam, The Netherlands. He received his $\mathrm{PhD}$ degree from the University of Utrecht on a thesis on laser-ion- and electron-beam-induced phase transformations in silicon in 1989. From 1989 to 1991 he was a research staff member at AT\&T Bell Laboratories (Murray Hill, NJ), where he studied the synthesis and properties of rare-earth implanted silica glasses.

In 1991 he started a group at the FOMInstitute, devoted to the synthesis, characterization, and application of novel optoelectronic materials. The group's research topics include rare-earth-doped optical waveguide materials, photonic bandgap materials, colloidal photonic materials, semiconductor nanocrystals, rare-earthdoped semiconductors, as well as the fundamentals of ion-solid interactions. In 1996, Polman was appointed as a parttime professor at the Debye Institute of Utrecht University. In 1999 he was appointed as head of the Optoelectronic Materials Department at AMOLF.

Polman serves on the editorial board of Materials Science and Engineering Reports, and is an Advisory Editor of Physica $B$. Along with serving MRS as a volume organizer for MRS Bulletin, he coauthored an article in the April 1998 issue of MRS Bulletin on the topic of siliconbased optoelectronics, and he has served as co-organizer of three symposia at MRS meetings in Boston and San Francisco (1994, 1996, 1997). 


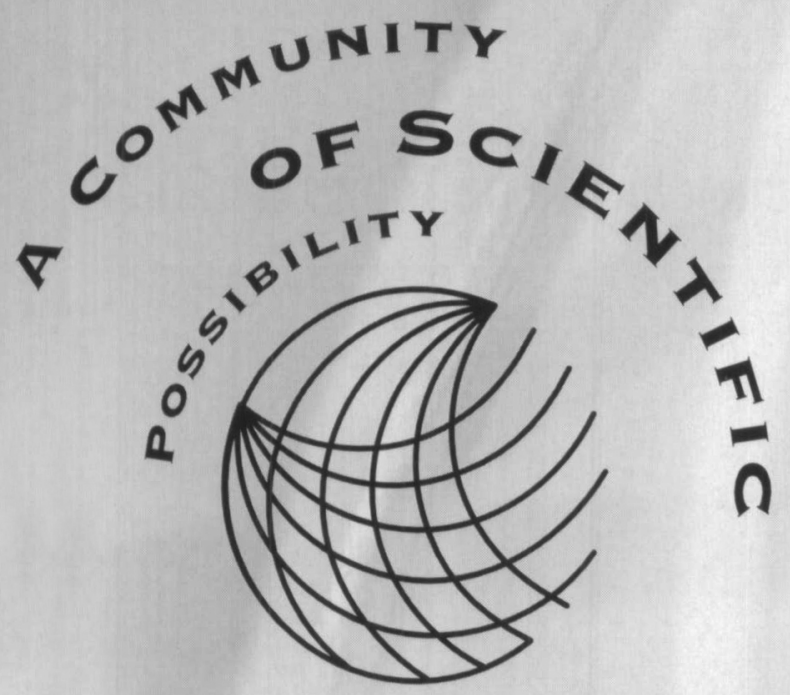

\section{Exciting NEW Benefits!}

\section{* FRE WEb ACCESS to MRS PROCEEDINGS \\ FREE Web access to four 1999 MRS Fall Meeting proceedings in early 2000 and 15 more from the 2000 MRS Spring Meeting before 2001.}

\section{* FREE WEB ACCESS TO JMR WITH YOUR MEMBER SUBSCRIPTION \\ Your discounted member subscription to Journal of Materials Research (MMR) includes FREE Web access at least $4-6$ weeks before print issue arrives in the mail!}

With the addition of these two benefits, the primary goal of the Materials Research Society (MRS) continues to be service...to its members and to the community of researchers in the science and engineering of modern materials. The Society's interdisciplinary approach differs from that of single-discipline professional societies because it promotes information exchange across the many technical fields touching materials development.

Take control of your professional destinyenroll today, and join the community of scientific possibility!

\section{CHECK OUT THESE \\ MEMBER BENEFITS \\ FOR THE YEAR 2000}

\section{- MRS MEETINGS \& WORKSHOPS}

Each year, more than 6000 members from around the world attend the MRS Spring and Fall Meetings and expand their professional network of contacts through the exchange of new ideas and information. MRS members enjoy reduced registration fees for these meetings and for the new MRS Workshop Series.

"For me, the Materials Research Society is an important and exciting part of the scientific experience and I look forward to the Spring and Fall Meetings each year. These meetings, with their international coverage and wonderful interdisciplinary nature, have enabled me to meet scientists from around the world working in many fields, and have broadened my understanding and enjoyment of materials science research."

-Frances M. Ross, IBM Research Division, Yorktown Heights, NY

\section{- NETWORKING OPPORTUNITIES \& CAREER SERVICES}

The annual Membership Directory is your connection to over 12,600 MRS members worldwide. In addition, the Society offers an Employment Center at both its Spring and Fall Meetings.

"Through various activities in MRS, I am constantly reconnected with old friends. I am always delighted to have an e-mail from out of the blue. And, I often turn to the MRS directory to contact an old colleague for a second opinion in an area that is new to me. We are all woven together with our interest in materials, but each lends a distinct strand to the fabric of MRS."

-Dr. Bethanie J. Stadler, University of Minnesota, Minneapolis, MN

\section{* University Chapters \& Sections}

MRS University Chapters are created on university campuses to foster discussion among students and faculty across a broad range of materials disciplines and to generate student interest in materials science. MRS Regional Sections provide local forums for the interaction of scientists and engineers in various materials disciplines of particular interest to that community. At present, MRS supports more than 40 active University Chapters and seven Sections.

"MRS is a great professional society for young materials scientists and engineers. I encourage my students to become MRS members and attend MRS meetings. I am pleased to say that UCLA was the first university to establish an MRS Student Chapter."

-Professor King-Ning Tu, University of California-Los Angeles, CA 


\section{MRS WWw.mrs.org}

Membership Application

(12 months) $\square$ NEW $\square$ RENEW

A. Start membership (check one):

a January 1,2000 D July 1, 2000 (Includes FREE access to new MRS proceedings online.)

$\begin{array}{lr}\text { Regular Membership } & \$ 100.00 \\ \text { Student Membership } & \$ 25.00 \\ \text { Retired/Unemployed } & \$ 25.00\end{array}$

$\$$

Retired/Unemployed

$\$ 25.00$

$\$$

$\$$

B. 2000 Member Subscription to Journal of Materials Research (Includes FREE access to the JMR online in 2000!)

and is FREE to MRS members. Journal of Materials Research (MMR) is the official journal of the Materials Research Society. Nearing its 15 th year, this archival publication is available to MRS members at a special discounted rate, and now includes FREE Web access with all print subscriptions.

"MRS keeps me up to date with the activities in the areas of my current interests, and exposes me to exciting possibilities for future interests."

$\rightarrow$ Professor Michael J. Aziz, Harvard University, Cambridge, MA

\section{- BOOKS \& VIDEOTAPES}

MRS publishes the proceedings of selected symposia as well as materials research related books. This series has become a standard reference in many areas of materials science and numbers over 620 volumes. MRS members may purchase these items at $15-30 \%$ off list price. FREE Web access to new electronic versions of MRS proceedings will also be available to MRS members in 2000 .

"The meetings and publications which MRS has developed provide excellent opportunities for both the multidisciplinary contacts and the awareness of new science and technologies which R\&D increasingly requires."

-Dr. Peter Lednor, Shell Research and Technology Centre, Amsterdam

\section{- AWARDS}

The MRS Awards Program acknowledges outstanding contributors to the progress of materials research, and recognizes their exciting and profound accomplishments. A variety of awards are offered to honor those whose work has already had a major impact in the field, as well as those whose work shows great promise for future leadership.

"For the past 20 years, the Materials Research Society has provided me with outstanding forums for meeting and interacting with a broad spectrum of materials researchers on both technical and professional matters. The technical meetings have allowed me to keep current in several areas of research, and the professional relationships that I have established with other researchers through committee work have proven invaluable."

-Alan I. Taub, Ford Motor Company, Dearborn, MI

$\begin{array}{lrr}\text { U.S. Member Rate } & \$ 85.00 & \$ \\ \text { Non-U.S. Member Rate (surface) } & \$ 100.00 & \$ \\ \text { Non-U.S. Member Rate (with air freight) } & \$ 180.00 & \$\end{array}$

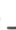

$\$$

$\$$

$\$$

Allow 6-8 weeks for delivery of any back issues of subscriptions. Dues allocated to MRS Bulletin Subscription: \$29 Regular, \$17 Student

\section{Mailing \& Billing Address}

\section{(Please Print)}

This address is: $\square$ Business $\square$ Home

\begin{tabular}{|c|c|c|c|c|c|}
\hline Name: First & & Middle & & Last & \\
\hline \multirow{2}{*}{ Institution } & \multicolumn{5}{|c|}{ Membership 10" } \\
\hline & $\square$ Institute & $\square$ Government & $\square$ Laboratory & $\square$ Industry & $\square$ Other \\
\hline \multicolumn{6}{|l|}{$\overline{D \text { opt./Moil Stop }}$} \\
\hline P.O. Box & & & Stroest & & \\
\hline Postal Code I & & & $\overline{c i r y}$ & & Possal Code 2 \\
\hline $\begin{array}{l}\text { Stote//Prosince } \\
\end{array}$ & & & Zip & & Countiy \\
\hline Tel: & Country & Aroo/Cirt & & Locol Number & \\
\hline Fax: & County & Areo/cing & & Locol Number & \\
\hline moil address & & & Ww oddress & & \\
\hline
\end{tabular}

NOTE: The address above will also be used in future MRS Membership Directories unless you request an alternate address for the Directory.

\section{Payment Information}

Check/money order enclosed

aill my credit card: a MasterCard a VISA aDiners Club a American Express

Card No.

Signature

Date

\section{Student Applicants}

I am currently enrolled as a full-time student, or I am working full-fime on a thesis or dissertation.

ignature Date

Return completed application to:

Member Services, Materials Research Society, 506 Keystone Drive, Warrendale, PA 15086-7573 U.S.A. • Tel 724-779-3003 • Fax 724-779-8313 • info@mrs.org 